Pesq. Vet. Bras. 36(5):383-388, maio 2016 DOI: $10.1590 / \mathrm{S} 0100-736 \mathrm{X} 2016000500005$

\title{
Identification of lamb flocks susceptible and resistant against Brachiaria poisoning ${ }^{1}$
}

\author{
Rayane C. Pupin², Gleice K.A. Melo², Rubiane F. Heckler², Tatiane C. Faccin ${ }^{3}$, Camila \\ C.B.F. Ítavo ${ }^{4}$, Carlos E. Fernandes ${ }^{5}$, Danilo C. Gomes ${ }^{4}$ and Ricardo A.A. Lemos ${ }^{4 *}$
}

\begin{abstract}
Pupin R.C., Melo G.K.A., Heckler R.F., Faccin T.C., Ítavo C.C.B.F., Fernandes C.E, Gomes D.C. \& Lemos R.A.A. 2016. Identification of lamb flocks susceptible and resistant against Brachiaria poisoning. Pesquisa Veterinária Brasileira 36(5):383-388. Laboratório de Anatomia Patológica, Faculdade de Medicina Veterinária e Zootecnia, Universidade Federal de Mato Grosso do Sul, Av. Senador Filinto Müller 2443, Campo Grande, MS 79074460, Brazil. E-mail: ricardo.lemos@ufms.br
\end{abstract}

This study was designed to assess the influence of genetic resistance against brachiaria poisoning in sheep. Two groups of sheep, one identified as susceptible (formed by two ewes and one ram) and the other as resistant against brachiaria poisoning (formed by three ewes and one ram) were selected. Sheep considered susceptible were those that presented clinical signs of brachiaria poisoning at any time of their life; resistant sheep were those that even raised on Brachiaria spp. pastures, did not developed any sign of the poisoning during their life. The offspring of the two flocks (15 lambs from the sensitive flock and 9 lambs from the resistant flock) were placed into brachiaria pasture (initially Brachiaria decumbens and B. brizantha, and only B. decumbens after weaning) and followed up during two years (2013-2014). The determination of protodioscin levels in B. decumbens pasture was performed only in 2014 and revealed significant amounts of the toxic principle. Eleven lambs of the susceptible group were affected to some degree of brachiaria poisoning and six died; no lamb of the resistant group was affected. Clinical signs consisted of varying degrees of subcutaneous edema of the face and, erythema and loss of hair of the ears, crusts on the skin of ears, around the eyes and on planum nasale, scar deformation of the ears, and bilateral ocular discharge; affected lambs also sought for shadowy shelters and they were poor doers. Several sheep recovered from the condition and then relapsed. Necropsy findings in six lambs included pale mucous membranes, emaciation, dermatitis, scar deformation of the ears, large yellow livers with marked lobular pattern, and moderate infestation by Haemonchus contortus. Histologically the liver lesions were similar in all necropsied lambs but with varying degrees of severity; they were consistent with brachiaria poisoning and included architectural disruption of hepatocellular trabecula, clusters of foamy macrophages occasionally forming multinucleated giant cells, swollen and vacuolated hepatocytes, crystals or negative images of crystals in the biliary system, bilestasis, bile duct proliferation and lymphoplasmacytic infiltrate in portal triads. The skin lesions were those of photodermatitis and included epidermal necrosis, hyperkeratosis and dermal neutrophilic infiltrate. The results of this study allow to conclude that there is a genetic related resistance to brachiaria poisoning in sheep since the progeny of resistant sheep did not manifest the poisoning. The use of resistant flocks

\footnotetext{
${ }^{1}$ Received on September 9, 2015.

Accepted for publication on March 7, 2016.

${ }^{2}$ Programa de Pós-Graduação em Ciência Animal, Universidade Federal de Mato Grosso do Sul (UFMS), Av. Senador Filinto Müller 2443, Campo Grande, MS 79070-900, Brazil.

${ }^{3}$ Programa de Pós-Graduação em Medicina Veterinária, Universidade Federal de Santa Maria (UFSM), Av. Roraima 1000, Santa Maria, RS 97105-000, Brazil.
}

\footnotetext{
${ }^{4}$ Faculdade de Medicina Veterinária e Zootecnia (FAMEZ), Universidade Federal de Mato Grosso do Sul (UFMS), Av. Senador Filinto Müller 2443, Campo Grande, MS 79070-900, Brazil. *Corresponding author: ricardo. lemos@ufms.br

${ }^{5}$ Centro de Ciências Biológicas e da Saúde (CCBS), Universidade Federal de Santa Maria (UFSM), Cidade Universitária s/n, Cx. Postal 549, Campo Grande, MS 79070-900, Brazil.
} 
in brachiaria pastures is suggested as a valuable option for the prevention of brachiaria poisoning in sheep.

INDEX TERMS: Poisonous plants, Brachiara spp., saponins, diseases of sheep, genetic resistance, plant poisoning.

RESUMO.- [Identificação de rebanhos de cordeiros suscetíveis e resistentes a intoxicação por braquiária.] Este estudo avaliou a resistência genética na ocorrência de intoxicação por braquiária em ovinos. Foram selecionados dois grupos de ovinos, um identificado como suscetível (formado por duas ovelhas e um carneiro) e o outro como resistente (formado por três ovelhas e um carneiro). Foram considerados suscetíveis ovinos que apresentaram sinais de intoxicação por Brachiaria spp. em algum ponto de suas vidas e resistentes aqueles ovinos que, mesmo criados em pastagem de braquiária, nunca desenvolveram qualquer sinal da intoxicação. A progênie desses dois grupos (15 cordeiros do grupo suscetível e 9 no grupo resistente) foi colocada numa pastagem de braquiária (inicialmente Brachiaria decumbens e B. brizantha e, após o desmame, apenas $B$. decumbens) e acompanhada durante dois anos (2013-2014). A determinação dos níveis de protodioscina em $B$. decumbens foi realizada apenas em 2014 e foram encontradas quantidades significativas do princípio tóxico. Onze cordeiros do grupo suscetível foram afetados por algum grau de intoxicação por braquiária; nenhum cordeiro do grupo resistente foi afetado. Os sinais clínicos consistiam de graus variáveis de edema subcutâneo da face e eritema e alopecia da pele das orelhas, crostas na pele das orelhas e ao redor dos olhos e no plano nasal, retração cicatricial das orelhas, fotofobia e corrimento ocular bilateral. Três cordeiros apresentaram desenvolvimento retardado. Vários cordeiros se recuperaram da condição, mas posteriormente quando foram colocados na pastagem apresentaram recidivas. Achados de necropsia em seis cordeiros incluíam mucosas pálidas, pobre condição corporal, dermatite, deformação cicatricial das orelhas, fígado aumentado de volume, amarelo e com padrão lobular evidenciado e graus moderados de infestação por Haemonchus contortus. Histologicamente, as lesões hepáticas eram semelhantes em todos os cordeiros necropsiados, mas apresentavam vários graus de intensidade; eram consistentes com as lesões de intoxicação por braquiária e consistiam de desorganização da arquitetura trabecular dos hepatócitos, agregados de macrófagos espumosos ocasionalmente formando células gigantes multinucleadas, hepatócitos tumefeitos e vacuolizados, cristais ou imagem negativa de cristais no sistema biliar, bilestase, proliferação de ductos biliares e infiltrado linfoplasmocitário nas tríades portais. As lesões da pele eram de fotodermatite e incluíam necrose da epiderme, hiperqueratose e infiltrado neutrofílico na derme. Os resultados desse estudo permitem concluir que há uma resistência genética à intoxicação por braquiária em ovinos, uma vez que a progênie dos ovinos resistentes não manifestou a intoxicação. 0 uso de rebanhos resistentes em pastagens e braquiária é sugerido como uma valiosa opção para prevenir a intoxicação por braquiária em ovinos.
TERMOS DE INDEXAÇÃO: Plantas tóxicas, Brachiaria spp., saponinas, doenças de ovinos, resistência genética, intoxicação por plantas.

\section{INTRODUCTION}

Large areas of cultivated pastures in Brazil consist of Brachiaria spp. (Tokarnia et al. 2012). The consumption of this forage by different farm animal species is associated with toxicosis being sheep and cattle the most susceptible (Lemos et al. 2011) and younger stock are more susceptible than mature animals (Albernaz et al. 2010, Castro et al. 2011, Mustafa et al. 2012). Furthermore, sheep from herds that never had contact with brachiaria species are more susceptible than sheep raised with free access to the plant (Lemos et al. 1996, Castro et al. 2007, 2011, Riet-Correa et al. 2011, Oliveira et al. 2012, Faccin et al. 2014). It is possible that animals raised in brachiaria pastures develop greater capacity in metabolize and degrade the steroidal saponin, the toxic principle of this type of grass (Castro et al. 2007) and/or development of a special ruminal flora (Albernaz et al. 2010) that make them able to reduce the effects of the toxin.

The typical clinical manifestation of Brachiaria spp. poisoning is photodermatitis. Affected animals show apathy, anorexia, icterus, skin pruritus, photophobia, serous ocular discharge, subcutaneous edema in the face and ears; in the skin of poorly pigmented areas there are lesions characterized by erythema, hair loss, and crusts. These areas evolve to necrosis and sloughing of patchy areas of affected skin, associated in many cases to deformity of the ears due to scarring of these lesions (Brum et al. 2007, Saturnino et al. 2010, Albernaz et al. 2010, Castro et al. 2011, Lemos et al. 2011, Mustafa et al. 2012, Oliveira et al. 2012, Faccin et al. 2014).

Main necropsy findings include icterus, enlarged yellow to orange discolored liver with marked lobular pattern, and distended gall bladder (Brum et al. 2007, Castro et al. 2007, 2011, Albernaz et al. 2010, Lemos et al. 2011, Mustafa et al. 2012, Oliveira et al. 2012, Faccin et al. 2014).

Histopathologically there is disruption of the hepatocyte trabecular arrangement with infiltration of foamy macrophages and, that occasionally coalesce to form multinucleated giant cells, hepatocytic swelling, individual hepatocellular necrosis, and bilestasis. In the portal triads there is periportal fibrosis, acicular birefringent crystals within bile ducts, bile duct proliferation and lymphoplasmacytic inflammatory infiltrate (Brum et al. 2007, Castro et al. 2007, 2011, Albernaz et al. 2010, Lemos et al. 2011, Riet-Correa et al. 2011, Mustafa et al. 2012, Oliveira et al. 2012, Faccin et al. 2014). Skin lesions are characterized by hyperkeratosis and parakeratosis, epidermal coagulative necrosis, necrotic debris, bacterial clumps, neutrophilic inflammatory infiltrate and necrosis of the dermal vessels (Lemos et al. 1996, Faccin et al. 2014). 
Brachiaria decumbens is the most toxic species of this genus; it may contain a concentration of more than $2 \%$ of the steroidal saponin, protodioscin (Riet-Correa et al. 2011, Barbosa-Ferreira et al. 2011).

Several measures to prevent or reduce the severity of the poisoning by brachiaria species in farm animals have been proposed. Among these are use as forage of less toxic (lower content of saponins) species o Brachiaria, like $B$. brizantha and B. humidicola (Riet-Correa \& Medeiros 2001, Riet-Correa et al. 2011) in which the concentrations of protodioscin are respectively $0,84 \% \pm 0,28$ and $0,11 \% \pm 0,02$ (Barbosa-Ferreira et al. 2011). However this is not completely safe since $B$. brizantha may, at times, accumulate concentrations of saponins high enough to cause intoxication in sheep (Albernaz et al. 2010, Faccin et al. 2014). An alternative measure of control is the identification of animals resistant to the intoxication by Brachiaria spp. (Riet-Correa \& Medeiros 2001, Riet-Correa et al. 2011) since it has already been reported that within one given herd there may be animals with different degrees of susceptibility (Castro et al. 2007, 2011, Saturnino et al. 2010).

Although conclusive data on the existence of genetic based resistance or susceptibility to Brachiaria spp. are still lacking, epidemiological evidences and experimental results indicated that the genetic make up could play a fundamental role in the resistance to this toxicosis (Melo 2014). The importance of a genetic associated resistance to a toxicosis was reported in association with the so called facial eczema, the mycotoxicosis caused by sporidesmin produced by Pithomyces chartarum (Morris et al. 1991)

The current study was design to assess the influence of genetic resistance on the occurrence of Brachiaria sp. poisoning in two flocks of sheep, one identified as susceptible and the other as resistant to the poisoning by Brachiaria spp.

\section{MATERIALS AND METHODS}

During the years of 2013 and 2014 two groups of lambs were observed. These two groups were the offering of a sheep herd consisting of susceptible and resistant animals and both were raised in pastures of Brachiaria brizantha and B. decumbens; there were histories of occurrence of outbreaks of photosensitization in this pasture. Sheep considered susceptible were those that presented clinical signs of brachiaria poisoning at any point of their lives; resistant sheep were those that even raised in Brachiaria spp. pastures, did not developed any sign of the intoxication at any time of their lives.

During the breeding season the herd was divided in two groups: one susceptible and one resistant. The original susceptible herd was formed by two susceptible ewes and a susceptible ram, and the resistant original herd by three resistant ewes and one resistant ram. Reproduction was by natural breeding keeping the rams with the ewes the whole time the breeding season. In the two years of the study the lamb produced by these breeding were kept in pastures of Brachiaria spp. with history of intoxication. Until weaning the lambs were kept in pastures consisting of $B$. decumbens and B. brizantha and after weaning (at 50 days of age) exclusively in $B$. decumbens.

During the experimental period, every 30 days, the number of eggs per gram of feces (EPG) were determined according to the technique Gordon and Whitlock (1939). The sheep whose EPG was above 500 were dewormed with levamisole (Ripercol ${ }^{\circledR}$ ).
Those lambs which presented any manifestation of clinically appreciable photosensitization were withdraw from the brachiaria pasture and held until clinical recover in stalls protected from the sun; during this time they were fed commercial ration for sheep, chopped Tifton-85 (Cynodon dactylon) hay and water ad libitum.

The lambs that spontaneously died or were euthanatized in the terminal phases or due to marked incapacity to reach an adequate corporal development were necropsied. Euthanasia was performed by intravenous injection of $4 \mathrm{mg} / \mathrm{kg}$ of body weight (bw) of ketamine associated with $0.2 \mathrm{mg} / \mathrm{kg} / \mathrm{bw}$ of xylazine hydrochloride followed intravenous potassium chloride. Fragments of several organs were sampled, fixed in 10\% formalin, processed routinely for histopathology and stained with hematoxilin and eosin (HE).

The determination of protodioscin in the pastures were made only in 2014. Samples from the grass were harvested at 28 days intervals from May to November, following the pattern of simulated animal grazing. To accomplish this pattern of consumption by the sheep was followed observing the heights and parts of the plant consumed, aiming to obtain a sample more closely to what the animal would spontaneously consume. To this end, the grass was grasped manually, in order to somewhat simulate the movement of the lips of lambs during grazing and then, a minimum of $200 \mathrm{~g}$ of grass were cut with a jack knife in a height similar to naturally cut by a grazing lamb (adapted from Cook 1964). The total sample obtained was placed in a forced-air ventilation stove at $55^{\circ} \mathrm{C}$, for 96 hours. The dried leaves harvest were passed through a Lab Willey grinder, with a sieve cloth mesh of $1 \mathrm{~mm}$ and send to the Chemistry laboratory of the Universidade Federal de Mato Grosso do Sul (UFMS) for protodioscin extraction and quantification by high-performance liquid chromatography (HPLC) using a evaporative light scattering detector (ELSD). Data obtained were evaluate statistically by the $G$ Test with a confidence margin of $\mathrm{P}<0.05$.

The experiment was approved by the UFMS Ethics Committee on the Experiments with animals and register under the number 400/2012.

\section{RESULTS}

During 2013, six lambs were born in the susceptible group - two of which developed clinical signs of brachiaria poisoning - and five in the resistant group, in which no cases of the toxicosis developed. During 2014, nine and four lambs were born respectively in the susceptible and resistant groups and there were eight cases of the toxicosis in former and no cases in the latter. All cases of brachiaria toxicosis occurred after weaning.

Overall, there were 15 lambs born in the susceptible group, of which ten developed clinical signs of photosensitization, eight of which presented relapses, two of which died. One of the lambs died without presenting photodermatitis and was heavily parasitized by Haemonchus contortus; however, this lamb had severe hepatic lesions of brachiaria poisoning. The morbidity rate was $73.33 \%$ and the mortality rate $20 \%$. Another three lambs on the susceptible group that had clinical signs and survived, were poor doers and were euthanatized at the end of the experiment.

No case of brachiaria poisoning was detect in any of the nine lambs from the resistant group. This is translated in a statistically significant difference $(p=0,006)$ in the incidence of the toxicosis between the two groups.

Clinical signs occurred in lambs with ages between 57 
Table 1. Poisoning by Brachiaria decumbens in lambs from the susceptible group that developed the toxicosis. Age (in days) of the lamb at first episode of photodermatitis (FEP), at the occurrence of relapses and clinical outcome

\begin{tabular}{|c|c|c|c|c|}
\hline Sheep ID ${ }^{a}$ & $\begin{array}{l}\text { Age at } \\
\text { FEP }\end{array}$ & $\begin{array}{c}\text { Number of } \\
\text { relapses }\end{array}$ & $\begin{array}{c}\text { Age at } \\
\text { relapses }\end{array}$ & Clinical outcome \\
\hline 327 & 57 & 0 & - & Recover \\
\hline 330 & 122 & 0 & - & Recover \\
\hline A04 & 74 & 1 & 158 & Died after first relapse $\mathrm{e}^{\mathrm{b}}$ \\
\hline \multirow[t]{2}{*}{ A06 } & 110 & 2 & 145 & \\
\hline & & & 178 & Euthanatized $^{c}$ \\
\hline $\mathrm{A} 07$ & 96 & 1 & 117 & Died after first relapse ${ }^{b}$ \\
\hline \multirow[t]{2}{*}{$\mathrm{A} 08$} & 83 & 2 & 109 & \\
\hline & & & 160 & Euthanatized $^{c}$ \\
\hline A11 & 128 & 1 & 180 & Recover \\
\hline A12 & 140 & 1 & 174 & Recover \\
\hline \multirow[t]{2}{*}{ A13 } & 82 & 3 & $\begin{array}{l}102 \\
134\end{array}$ & \\
\hline & & & 169 & Euthanatized $^{\mathrm{b}}$ \\
\hline $\mathrm{A} 18^{\mathrm{d}}$ & $109^{\mathrm{e}}$ & 0 & - & Died due to haemonhcosis \\
\hline A20 & 93 & 1 & 137 & Recover \\
\hline
\end{tabular}

adentification; ${ }^{\mathrm{b}}$ submitted to liver biopsy; 'euthanasia at the end of the experiment; ${ }^{d}$ in spite of lack of clinical signs of the intoxication, hepatic lesions of similar type and intensity as those of lambs(A04, A07) with clinical signs of photodermatitis were found in this lamb; eage of death.

and 150 days, that is, 7 to 90 days after weaning. These included varying degrees of subcutaneous edema of the face and ears (8 out of 10 lambs), reddening and loss of hair of the ears $(6 / 10)$, crusts in the ears and planum nasale $(5 / 10)$, scar deformation of the ears $(3 / 10)$, bilateral ocu- lar secretion (2/10); affected lambs seek for shadowy shelters $(2 / 10)$.

There were no clinical relapses detected in 2013. However, during 2014 all the lambs that got sick relapsed at some point. Three lambs had only one episode of relapse in 34-84 days after the first outburst of clinical disease. The three euthanatized lambs had clinical relapses, two of these lambs presented two relapses each within intervals of 26 to 52 days after the first outburst of clinical signs; the other lamb had three relapses with intervals of 20 to 35 days after the first clinical outburst. Another two lambs died after one relapse (Table 1). One lamb died from haemonchosis (A18 in Table 1); in spite of lack of clinical signs of the intoxication in this lamb, similar lesions in type and severity as those described above for the two lambs (AO4, A07) with photodermatitis were observed.

Altogether six lambs died during the experiment. Necropsy findings in these six lambs are summarized in Table 2.

Histologically the lesions observed in the livers from lambs that died were similar but with varying degrees of severity (Table 3 ).

No determination of protodioscin levels was carried out in the pasture during 2013. Levels of protodioscin found in the pasture during 2014 are expressed in Figure 1.

According to CEMTEC-AGRAER 6 , total rain precipita-

\footnotetext{
${ }^{6}$ Centro de Monitoramento do Tempo, do Clima e dos Recursos Hídricos de Mato Grosso do Sul, Agência de Desenvolvimento Agrário e Extensão Rural.
}

Table 2. Brachiaria decumbens poisoning in lambs from susceptible flocks. Necropsy findings in six lambs that died or were euthanatized due to effects of the toxicosis

\begin{tabular}{|c|c|c|c|c|c|c|c|}
\hline Lamb ID & $\begin{array}{l}\text { Nutricional } \\
\text { score }\end{array}$ & $\begin{array}{c}\text { Pale mucous } \\
\text { membranes }\end{array}$ & $\begin{array}{l}\text { Crust in the } \\
\text { skin (ears and } \\
\text { around the eyes) }\end{array}$ & $\begin{array}{c}\text { Scar } \\
\text { deformation } \\
\text { of the ears }\end{array}$ & $\begin{array}{c}\text { Liver: yellow, enlarged } \\
\text { and with marked } \\
\text { lobular pattern }\end{array}$ & Icterus & $\begin{array}{l}\text { Haemonchus contortus } \\
\text { specimens in abomasum }\end{array}$ \\
\hline
\end{tabular}

\begin{tabular}{|c|c|c|c|c|c|c|c|}
\hline $\mathrm{A} 04^{\mathrm{a}}$ & $\mathrm{P}$ & + & ++ & - & + & + & ++ \\
\hline$A 06^{b}$ & I & +++ & - & - & - & - & ++ \\
\hline $\mathrm{A} 07^{\mathrm{c}}$ & $\mathrm{P}$ & ++ & +++ & +++ & + & ++ & ++ \\
\hline $\mathrm{A} 08^{\mathrm{b}}$ & I & ++ & ++ & +++ & - & - & ++ \\
\hline $\mathrm{A} 13^{\mathrm{b}}$ & I & ++ & +++ & - & + & - & - \\
\hline $\mathrm{A} 18^{\mathrm{d}}$ & $\mathrm{P}$ & +++ & - & - & + & ++ & -e \\
\hline
\end{tabular}

a Spontaeous death; ${ }^{b}$ euthanatized as poor doers; ${ }^{c}$ euthanatized in extremis due to advanced manifestation of the toxicosis; ${ }^{d}$ death from haemonchosis


is explained be the deworming carried out just prior to death; $\mathrm{P}=$ proper body development for the age; $\mathrm{I}=$ inappropriate body development for the age; - = absence of lesion, += mild lesion; ++ = moderate lesion; +++= marked lesion.

Table 3. Brachiaria decumbens poisoning in lambs from susceptible flocks. Histopathological findings in six lambs that died or were euthanatized due to effects of the toxicosis

\begin{tabular}{|c|c|c|c|c|c|c|c|c|c|c|c|}
\hline \multirow[b]{2}{*}{ Lamb ID } & \multicolumn{8}{|c|}{ Liver } & \multicolumn{3}{|c|}{ Skin } \\
\hline & $\begin{array}{l}\text { Architectural } \\
\text { disruption of } \\
\text { hepatocellular } \\
\text { tabeculae }\end{array}$ & $\begin{array}{l}\text { Foamy } \\
\text { macro- } \\
\text { phages }\end{array}$ & $\begin{array}{c}\text { Swollen } \\
\text { and } \\
\text { vacuolated } \\
\text { hepatocytes }\end{array}$ & $\begin{array}{l}\text { Crystals or } \\
\text { negative image } \\
\text { of crystals } \\
\text { in the biliary } \\
\text { system }\end{array}$ & $\begin{array}{l}\text { Mutinucleated } \\
\text { foamy } \\
\text { giant } \\
\text { cells }\end{array}$ & Bilestasis & $\begin{array}{c}\text { Bile } \\
\text { duct } \\
\text { prolife- } \\
\text { ration }\end{array}$ & $\begin{array}{l}\text { Lymphoplas- } \\
\text { mocytic infil- } \\
\text { trate in portal } \\
\text { triads }\end{array}$ & $\begin{array}{l}\text { Epidermal } \\
\text { necrosis }\end{array}$ & $\begin{array}{l}\text { Hyperke- } \\
\text { ratosis }\end{array}$ & $\begin{array}{c}\text { Neutrophilic } \\
\text { infiltrate }\end{array}$ \\
\hline
\end{tabular}

\begin{tabular}{|c|c|c|c|c|c|c|c|c|c|c|c|}
\hline $\mathrm{A} 04^{\mathrm{a}}$ & ++ & +++ & - & + & + & - & ++ & - & ++ & + & ++ \\
\hline$A 06^{b}$ & - & +++ & ++ & - & +++ & - & - & - & - & - & - \\
\hline $\mathrm{A} 07^{\mathrm{c}}$ & ++ & +++ & +++ & ++ & - & + & - & - & - & +++ & + \\
\hline $\mathrm{A} 08^{\mathrm{b}}$ & - & - & ++ & - & + & - & - & - & - & + & - \\
\hline $\mathrm{A} 13^{\mathrm{b}}$ & - & + & ++ & - & - & - & - & + & +++ & ++ & ++ \\
\hline $\mathrm{A} 18^{\mathrm{d}}$ & +++ & ++ & + & ++ & - & + & - & - & - & - & - \\
\hline
\end{tabular}

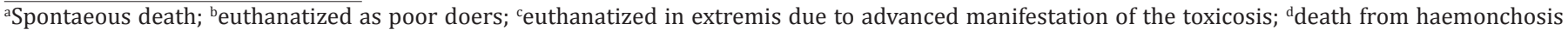
associated with severe hepatic lesions attributed to brachiaria toxicosis. - = absence of lesion, += mild lesion; ++ = moderate lesion; +++= marked lesion. 


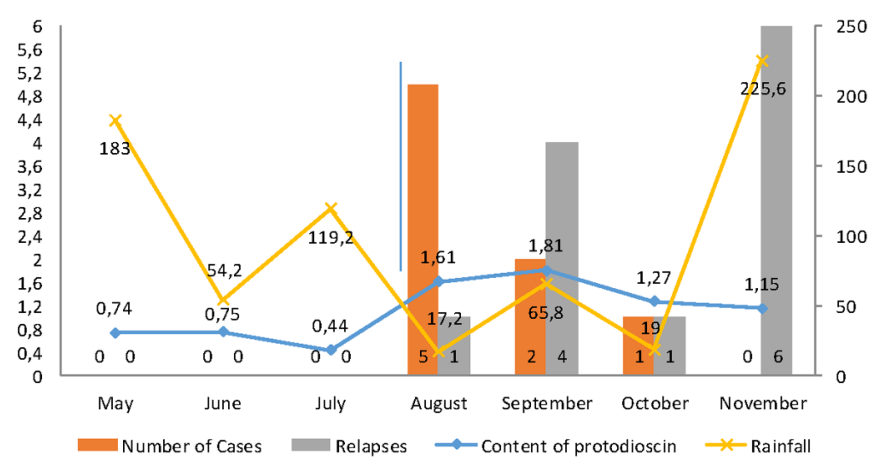

Fig.1. Determination of the amounts of protodioscin in Brachiaria decumbens samples during 2014. The samples were obtained by the "simulated grazing method". The levels of protodioscin are expressed in percentage of the dry matter.

tion during May-November varied from $17.20 \mathrm{~mm}$ and $225.60 \mathrm{~mm}$. Minimum and maximum values of rain precipitation were observed respectively on August and November. There was no correlation observed between the protodioscin levels in the pastures and the total monthly rain precipitation.

\section{DISCUSSION}

Eleven out of the 15 lambs selected as part of the susceptible group developed some degree of Brachiaria decumbens poisoning while none of the nine lambs of the resistant group was affected, which had a statistically significance between the two groups suggesting a genetic induced resistance to brachiaria poisoning in sheep. Although there are circumstantial evidences that genetics play an important role in the resistance to this toxicosis (Riet-Correa et al. 2011) and different degrees of individual susceptibility have been demonstrated (Castro et al. 2007, 2011, Saturnino et al. 2010, Faccin et al. 2014), up to date there were no reported studies comparing descendants lambs from susceptible and resistant progenitors in relation to Brachiaria spp. poisoning. Studies evaluating the importance of genetic on the resistance to other weed induced toxicosis were done in relation to facial eczema. The inheritance of resistance to facial eczema (mycotoxicosis induced by sporidesmin from Pithomyces chartarum) in cattle was already demonstrated (Morris et al. 1991). The greater vulnerability in the susceptible group in the current study was stressed by the occurrence of relapses in eight out of 10 lambs that showed clinical signs of photodermatitis.

Our findings support the hypothesis of inherited resistance to Brachiaria decumbens poisoning, since the time elapsed between relapses is more likely enough for the clearance of the toxic principle and complete recover of the hepatic tissue. Although there are no reports about period necessary to eliminate protodioscin avoiding a possible accumulative effected, in none of the lambs of this study that relapsed were there chronic hepatic lesions in the histopathological exam. Out of 11 lambs that got sick in the susceptible group, six died naturally or were euthanatized as poor doers, and five recovered. This set of results suggests that adaptation of susceptible lambs may occur as the consumption of the plant goes on. It is interesting to point out that the lambs of the current study were observed continuously and were withdrawn from the brachiaria pasture immediately after the onset of clinical signs, which may influence in decreasing the lethality rate, inversely to which occur in flocks raised extensively in which the identification of the onset of clinical signs is difficult, decreasing de likelihood that poisoned animals survive.

Death of susceptible animals lead to a natural selection process allowing for the emergence of resistant flocks as the duration of their permanence in the infested Brachiaria spp. pasture increases, as has been the case in sheep and cattle herds of Midwestern Brazil (Riet-Correa et al. 2011, Faccin et al. 2014). However it should be pointed out that high mortality rates may occur in lambs after the introduction of susceptible ram in a resistant flock (Melo 2014).

The clinic-pathological presentation of the affected lambs of this study lambs were close similar to what has been reported for Brachiara spp. poisoning (Brum et al. 2007, Castro et al. 2007, 2011, Saturnino et al. 2010, Albernaz et al. 2010, Lemos et al. 2011, Mustafa et al. 2012, Oliveira et al. 2012, Faccin et al. 2014).

The lack of correlation between the protodioscin levels in the pasture and the rain precipitation rates differs to what was found by others (Faccin et al. 2014). Concentrations of protodioscin in May-July, when higher rates of rain precipitation occurred were marked lower than those observed from August to October, when rain precipitation rates were lower and was when the clinical cases occurred. Besides the higher levels of protodioscin in the pastures, the weaning may have contributed to the occurrence of the toxicosis as after weaning $B$. decumbens - which is considered the most toxic of the genus (Riet-Correa et al. 2011, Tokarnia et al. 2012) - was the only choice for the lambs to graze. However, it must also be considered that poisoning in the lambs of the current study occurred only after the separation of the lambs from the ewes which induced intake greater amounts of $B$. decumbens by the lambs. The onset of clinical signs occurred respectively seven and 24 days after weaning, while during 2013 and 2014. We were unable to find any specific information in the literature on the relation of photosensitization and weaning in sheep; however, studies carried out in cattle mention a greater incidence of cases of brachiaria poisoning after weaning and introduction of the weaned calves to pastures that were not grazed for certain amount of time before the introduction of the calves (Tokarnia et al. 2012), due to greater ingestion of brachiaria after the discontinuation of suckling (Fagliari et al. 1994).

One of the lambs of the susceptible group died with the diagnosis of haemonchosis, but had severe histopathological hepatic changes, compatible with brachiaria poisoning. It was considered that the hepatic lesions have contributed to this lamb dismay. Another three were euthanatized due to poor thriving. Thus, in addition to the loss by death of animals, brachiaria poisoning may be the and underneath factor related to increased susceptibility to another diseases and loss of productivity, since some lambs, able to survive the toxicosis, become poor doers that are not economical feasible to raise. Although there are reports that animals susceptible to the poisoning by certain plants demonstrate 
lesser development degrees and productivity and reproduction, and decreased resistance to verminosis (Oliveira Júnior et al. 2011), there are no reports of this latter aspect and brachiaria poisoning. Cases of wasting associated with brachiaria poisoning are reported in cattle (Riet-Correa et al. 2002, Souza et al. 2010). The loss of weight in these cases were attributed to a malabsorption syndrome induced by the infiltration of foamy macrophages in the intestinal mucosa (Riet-Correa et al. 2002) which was not corroborated by other authors (Souza et al. 2010). In the current study the cause of poor development in three lambs remains undetermined since these lambs did not have neither gross nor histopathological lesions that could explain this clinical presentation, such as diffuse hepatic fibrosis or foamy macrophages infiltrating in the intestine.

Although there were no determination of protodioscin levels during 2013, the occurrence of two cases - one in June and another in September of this year - in the same pasture where the cases of the next year occurred, allow the inference that there was toxic concentrations of protodioscin in the pasture. The methodology for the evaluation of concentrations of protodioscin in the pasture in 2014 proved to be adequate, however it is no possible to compare the efficiency with other studies (Brum et al. 2007, Castro et al. 2007, 2011, Faccin et al. 2014) since they used different methods for the evaluation.

In conclusion, the lambs of this study had a genetic resistance to brachiaria poisoning since the progeny of resistant sheep did not manifest the toxicosis, indicating the investment in genetically resistant flocks may be a valuable option for prevent poisoning by Brachiaria spp. in sheep.

Acknowledgements.- This study was funded by grants of the Conselho Nacional de Desenvolvimento Científico e Tecnológico (CNPQ, grant number 14/2011, 483211), Instituto Nacional de Ciência e Tecnologia para o Controle das Intoxicações por Plantas (INCT/CNPq, 573534/2008-0), by the Fundação de Apoio ao Desenvolvimento do Ensino, Ciência e Tecnologia do Estado de Mato Grosso do Sul (FUNDECT/CNPq, grant number 15/2014 - PRONEM - MS).

\section{REFERENCES}

Albernaz T.T., Silveira J.A.S., Silva N.S., Oliveira C.H.S., Reis A.S.B., Oliveira C.M.C., Duarte M.D. \& Barbosa J.D. 2010. Fotossensibilização em ovinos associada à ingestão de Brachiaria brizantha no estado do Pará. Pesq. Vet. Bras. 30:741-748.

Barbosa-Ferreira M.B., Brum K.B., Oliveira N.M.R., Valle C.B., Ferreira V.B.N., Garcez V., Riet-Correa F. \& Lemos R.A.A. 2011. Concentração da saponina esteroidal protodioscina em diferentes espécies e cultivares de Brachiaria spp. Vet. Zootec., 18 (suppl. 3):98-113.

Brum K.B., Haraguchi M., Lemos R.A.A., Riet-Correa F. \& Fioravante M.C.S. 2007. Crystal-associated cholangiopathy in sheep grazing Brachiaria decumbens containing the saponin protodioscin. Pesq. Vet. Bras. 27:39-42.

Castro M.B., Moscardini A.R.C., Reckviegel G.C., Novaes E.P.F., Mustafa V.S., Guedes K.M.R., Paludo G.R., Borges J.R. \& Riet-Correa F. 2007. Suscetibilidade de ovinos a intoxicação por Brachiaria decumbens. Proceedings 5은 Congresso Latino Americano de Especialistas en Pequeños Rumiantes y Camélideos Sudamericanos, Mendoza, Argentina, p.57-59.
Castro M.B., Santos Jr. H.L., Mustafa V.S., Gracindo C.V., Moscardini A.C.R., Louvandini H., Paludo G.R., Borges J.R.J., Haraguchi M., Ferreira M.B. \& Riet-Correa F. 2011. Brachiaria spp. poisoning in sheep in Brazil: experimental and epidemiological findings, p.110-117. In: Riet-Correa F., Pfister J., Schild A.L. \& Wierenga T. (Eds), Poisoning by Plants, Mycotoxins and Related Toxins. CAB International, Wallingford, UK.

Cook C.W. 1964. Symposium on nutrition of forages and pastures: collecting forage samples representative of ingested material of grazing animals for nutritional studies. J. Anim. Sci. 23:265-270.

Faccin T.C., Riet-Correa F., Rodrigues F.S., Santos A.C., Melo G.K.A., Silva J.A., Ferreira R., Ítavo C.C.B. \& Lemos R.A.A. 2014. Poisoning by Brachiaria brizantha in flocks of naïve and experienced sheep. Toxicon 82:1-8.

Fagliari J.J., Okuda H.T., Kuchembuck M.R.G. \& Curi P.R. 1994. Intoxicação natural de bovinos pela micotoxina esporidesmina. I. Aspectos epidemiológicos. Arq. Bras. Med. Vet. Zootec. 45:263-274.

Gordon H.M.C.L. \& Whitlock H.V. 1939. A new technique for counting nematode eggs in sheep faeces. JSIR 12:50-52.

Lemos R.A.A., Ferreira L.C.L., Silva S.M., Nakazato L. \& Salvador S.C. 1996. Fotossensibilização e colangiopatia associada a cristais em ovinos em pastagem com Brachiaria decumbens. Ciência Rural 26:109-113.

Lemos R.A.A., Nogueira A.P.A., Souza R.I.C., Santos B.S., Carvalho N.M., Aniz A.C.M. \& Freitas P.C. 2011. Brachiaria spp. poisoning in ruminants in Mato Grosso do Sul, Brazil, p.129-132. In: Riet-Correa F., Pfister J., Schild A.L. \& Wierenga T. (Eds), Poisoning by Plants, Mycotoxins and Related Toxins. CAB International, Wallingford, UK.

Melo G.K.A. 2014. Desempenho de cordeiros lactentes suplementados em cocho privativo em pastagem de Brachiaria spp. Dissertação de Mestrado, Programa Ciência Animal, Universidade Federal de Mato Grosso do Sul, Campo Grande, MS. 62p.

Morris C.A., Towers N.R., Smith B.L. \& Southey B.R. 1991. Progeny testing bulls for susceptibility to facial eczema. N.Z. J. Agric. Res. 34:413-417.

Mustafa V.S., Moscardini A.R.C., Borges J.R.J., Reckziegel G.C., Riet-Correa F. \& Castro M.B. 2012. Intoxicação natural por Brachiaria spp. em ovinos no Brasil Central. Pesq. Vet. Bras. 32:1272-1280.

Oliveira R.S., Silva R.M.M., Dutra P.A., Ferreira E.A., Pinheiro E.E.G., Macêdo J.T. \& Pedroso P.M.O. 2012. Intoxicação espontânea por Brachiaria decumbens em ovinos no estado da Bahia. Arq. Pesq. Anim. 1:58-63.

Oliveira Júnior C.A., Riet-Correa F., Duarte M.D., Cerqueira V.D., Araújo C.V. \& Riet-Correa G. 2011. Sinais clínicos, lesões e alterações produtivas e reprodutivas em caprinos intoxicados por Ipomea carnea subsp. fistulosa (Convolvulaceae) que deixaram de ingerir a planta. Pesq. Vet. Bras. 31:953-960,

Riet-Correa F. \& Medeiros R.M.T. 2001. Intoxicações por plantas em ruminantes no Brasil e no Uruguai: importância econômica, controle e riscos para a saúde publica. Pesq. Vet. Bras. 21:38-42.

Riet-Correa G., Riet-Correa F., Schild A.L. \& Driemeier D. 2002. Wasting and death in cattle associated with chronic grazing of Brachiaria decumbens. Vet. Human Toxicol. 44:179-180.

Riet-Correa B., Castro M.B., Lemos R.A.A., Riet-Correa G., Mustafa V. \& Riet-Correa F. 2011. Brachiaria spp. Poisoning of ruminants in Brazil. Pesq. Vet. Bras. 31:183-192.

Saturnino K.C., Mariani T.M., Barbosa-Ferreira M., Brum K.B., Fernandes C.E.S. \& Lemos R.A.A. 2010. Intoxicação experimental por Brachiaria decumbens em ovinos confinados. Pesq. Vet. Bras. 30:195-202.

Souza R.I.C., Riet-Correa F., Brum K.B., Fernandes C.E., Barbosa-Ferreira M. \& Lemos R.A.A. 2010. Intoxicação por Brachiaria spp. em bovinos no Mato Grosso do Sul. Pesq. Vet. Bras. 30:1036-1042.

Tokarnia C.H., Brito M.F., Barbosa J.D., Peixoto P.V. \& Döbereiner J. 2012. Plantas/micotoxinas fotossensibilizantes, p.323-335. In: Ibid. (Eds), Plantas Toxicas do Brasil para Animais de Produção. 2 $2^{\underline{a}}$ ed. Helianthus, Rio de Janeiro. 